\title{
Sustainability: increasing impact on textile and apparel industry
} Keywords: sustainability, textiles, apparel, fashion, environmen-
tal impact

\section{Introduction}

The well known economic problem for centuries is the problem of how to make the best use of limited, or scarce, resources. This problem still exists to continue but it is likely to get even worse unless necessary precautions are taken. A simple solution is to comply with the rules of a sustainable planet. Sustainability is based on a simple and long-recognized factual premise: Everything that humans require for their survival and well-being depends, directly or indirectly, on the natural environment as stated by Marsh. ${ }^{1,2}$ The air we breathe, the water we drink, and the food we eat, all are provided by the environment which has been unintentionally jeopardized by human beings on the cost of an overrun civilization.

All societies face this economic problem. Paul Samuelson, the Nobel Prize winner for economics, is often credited with providing the first clear and simple explanation of the economic problem. He stated $^{3}$ that in order to solve the problem of scarcity; all societies, no matter how big or small, developed or not, must endeavor to answer three basic questions:

\section{What to produce? How to produce? For whom to pro- duce?}

Answering these questions is not so simple and certainly there is no single common reply to that. The people should decide the best combination of goods and services to meet their needs. For example, how many resources should be allocated to consumer goods, and how many resources to capital goods, or how many resources should go to education or defense? They also have to decide the best combination of factors to create the desired output of goods and services. Finally, all societies need to decide who will get the output from the country's economic activity, and how much they will get. For example, who will get the fashion products, computers and cars which have been produced? This is often called the problem of distribution. It is another problem that various economic systems have yet failed to provide a virtuous solution.

The appropriate answers to that question are somehow stipulated within the concept of sustainability. Sustainability defines, in fundamental ways, the communities in which we live and is the source for renewable and non renewable resources on which civilization depends. Our health and well-being, our economy, and our social life and safety all require a high quality environment. ${ }^{2}$ If we act on that understanding, we tend to prosper; if not we would be liable to suffer.

Eventually, continuous advancement of industrialization and sophistication of technologies have improved the quality of life on the expenses of resource depletion, environment destruction and global warming. Partly negligence and partly unconscious act of most communities have gradually worsened the environmental issues we are facing today. Therefore, a new roadmap was inevitable. The World Commission on Environment and Development, chaired by
Volume 2 Issue 5 - 2017

\author{
H Ziya Ozek \\ Department of Textiles Engineering, Namik Kemal University, \\ Turkey
}

Correspondence: $\mathrm{H}$ Ziya Ozek, Department of Textiles Engineering, C Faculty of Engineering, Namik Kemal University, Corlu, 59860 Tekirdag, Turkey, Tel 902822502304 , Email zozek@nku.edu.tr

Received: August 01, 2017 | Published: August 29, 2017

former Norwegian Prime Minister G. Harlem Brundtland, alerted the world twenty years ago to the urgency of making progress toward economic development that could be sustained without depleting natural resources or harming the environment. It was introduced as Sustainable development in 1987. It is defined as "development that meets the needs of the present without compromising the ability of future generations to meet their own needs" in Our Common Future which is known as the Brundtland Report. ${ }^{4}$

In general, sustainability is focused on three different aspects; economic sustainability, social sustainability and environmental sustainability. Each segment is vitally important, but it is worth reminding that without economic (or financial) sustainability, not enough attention has been paid to environmental (ecological) sustainability and social sustainability. Furthermore, four key areas for activity all of which impact upon the world trade and professional life of those in the design and construction industries: sustainable production and consumption (changing the way products and services are designed, produced, etc.); climate change and energy usage (reducing greenhouse gas emissions and adapting to future climate change); scarcity of natural resources (understanding the limits of resources); and sustainable communities (maintaining existing urban resources and building an energy efficient culture.)

Currently, the knowledge of sustainability has considerably increased and several approaches and research for sustainable production have been presented. So far, progress towards sustainable forms of production and consumption has been noticeable but very modest. It is necessary to pay attention to both the design and manufacturing and business model approaches when applying sustainability. Though there is increasing literature on the sustainable business model and sustainable production, little attention has been paid to solution design's implication for the sustainability. Furthermore, if one replaces 'development' with 'fashion', this task becomes more complicated.

Until the last decade, product development activities in the textile and apparel industry have focused on technological and cost 
aspects. The maximum emphasis has been placed on keeping the price of the final product low and increasing efficiency in production processes. Neither manufacturers and retailers nor designers have paid any attention to other dimensions such as consumer demands or environmental impact. Hence, the products are designed and produced according to regularly changing trends that enable quick profit, rather than radically rethinking the ways of designing and manufacturing the product that is based on consumer needs and sustainability. This trend has changed now and how textile and clothing offerings should be designed and manufactured to better suit consumer demands in a more sustainable way has become to be often questioned.

Textiles and fashion is one of the most polluting industries in the world. Every stage in a garment's life, from the attainment of fiber to the disposal (which is termed as "cradle to grave"), threatens our planet and its resources and also social life standards. These stages and possible social, economic and environmental impacts are listed in Figure 1. It can take around 7,000-29,000 litres of water to produce $1 \mathrm{~kg}$ of cotton clothing. This is roughly equivalent to a single t-shirt and pair of jeans. Up to 8,000 different chemicals are used to turn raw materials into clothes, including a range of dyeing and finishing processes. The amount of chemicals used for $1 \mathrm{~kg}$ of finished textiles varies between $1.5-6.9 \mathrm{~kg}$. Approximately one quarter of world consumption of insecticide is spent for textile industry. ${ }^{5}$ The world average fiber consumption per capita in 2015 has grown to $13 \mathrm{Kg}$ from $2 \mathrm{~kg}$ in 1900 's. This figure goes over $20 \mathrm{Kg}$ for developed nations. And what becomes of the clothing that doesn't sell falls apart or goes out of style? More often than not, it is discarded in giant landfills. The total amount of worldwide waste by the Textile and Clothing Industry is reported as 90 million tones in $2011 .{ }^{5}$ How can the fashion industry become more sustainable?

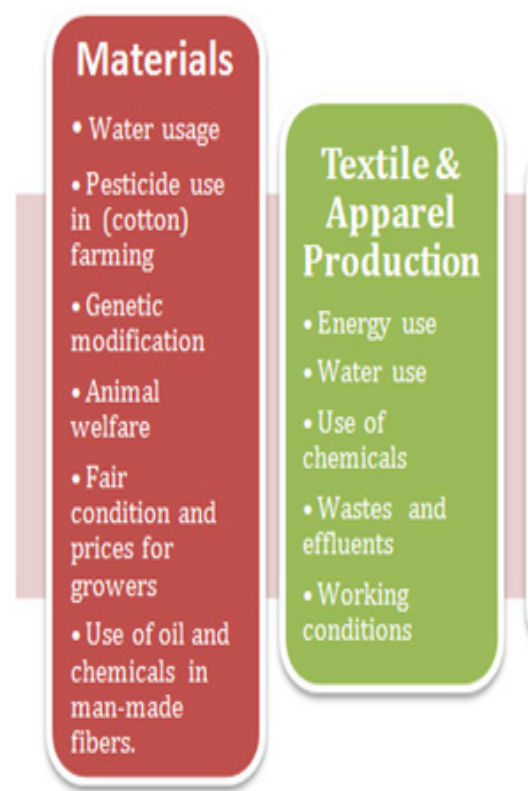

Figure I The Life cycle of textile and apparels from cradle to grave.

In the European Union, the Registration, Evaluation, Authorization and Restriction of Chemicals (REACH) regulations enacted 1 June 2007 require clothing manufacturers and importers to identify and quantify the chemicals used in their products. The Greenpeace Detox campaign $^{6}$ starting in 2011 targeted the elimination of hazardous chemicals which are coming under continued and increasing scrutiny. Since then, Greenpeace has been calling on the clothing industry to eliminate all hazardous chemicals from its supply chain. Certain legislative and voluntary restrictions are consequently implemented across the industry. A group of leading textile associations and some brands made a commitment, in 2011, to set the Zero Discharge of Hazardous Chemicals (ZDHC) in the supply chain by 2020 . The Joint Roadmap report of this collaboration was published in 2012. ${ }^{7}$ Main focus point of several roadmap projects is to carry out active research on various chemistries like durable water repellents that will afford high performance with less environmental impact. The manufacturers of textile machinery are also engaged in sustainability. The thema in the last ITMA -2015 fair in Milan was sustainability. The manufacturers are very much concerned about lower energy consumption, limitation in water usage, recovery of heat and reduction in all kinds of wastes.

In this context a new approach is presented as Green Chemistry. It is essentially a way of thinking rather than a new branch of chemistry and is about utilizing a set of principles that seek to reduce the adverse environmental impact of chemical processes and products and to contribute to sustainable development. ${ }^{8}$ It deals with new sciences and technologies to prevent the formation of any waste by life cycle assessment (LCA). Principles and objectives of green chemistry are varied..$^{9,10}$ Elimination or minimization of waste, safer and nontoxic products, direct reactions with minimum or fewer steps and Renewable and not depleting feedstock are some of them. Challenges for green chemistry which are also concern of all manufacturers and designers are listed below: ${ }^{9,11}$

a. Renewable feedstock, preferably non-food plants and their full conversion to useful products,

b. Reactions having minimum environmental impact, for example, use of eco-friendly organic catalysts.

c. Industrial processes and reactors having maximum efficiency and minimum waste,

d. Products of reduced toxicity and increased biodegradability to substitute environmentally harmful chemicals. 
e. Prediction of chemical and biological properties of compounds from their chemical structures.

f. Cleaner solvents as replacements of the flammable, toxic and volatile solvents polluting atmosphere.

We all need to think that how is all this clothing made and what is it doing to our planet? Sustainable textiles are designed to address a growing awareness of such issues. Kawamura ${ }^{12}$ discussed that fashion and clothing is distinct concepts; fashion is immaterial, while clothing is material. On the one hand, it seems to make sense, especially in our time when fashion imagery may present a fantasy world. This perception of fashion does not seem problematic in the context of sustainability. On the other hand, we must admit that fashion drives changes in the clothing itself. As soon as fashion is combined with a process and a product or defined as a cultural industry that establishes the aesthetic and practical dimensions of our clothing habits, the material of the product and pace of change become vital. ${ }^{13}$

Fashion is a unique tangible consumer product featuring; timeliness, styles, trendiness, and many knock-offs. Although fashion is no longer regarded as a necessity product, it is almost a must-buy product for every season. Fast fashion provides the marketplace with affordable apparel aimed mostly at young people. Fashion magazines also help to promote the demand and desire for new "must-haves" for each season. "Girls especially are insatiable when it comes to fashion. When it is cheap, you buy more of it. On the other hand, fast fashion leaves a pollution footprint, with each step of the clothing life cycle generating potential environmental and occupational hazards as stated above. In contrast, Slow Fashion refers to the style, design and quality of a garment, as well as the intention behind how it was made. It involves buying clothing made of durable fabrics and staying away from fluctuating trends so you can still wear the pieces you love for years. As stated by Papanek, ${ }^{14}$ the aim of sustainability in fashion may be rather clear but the methods of reaching sustainability are not clear at all. Sustainable fashion is a complex effort, including a lot of idealism, but its many elements have to be taken into consideration on a practical level. A strict definition for sustainability is made by Chouinard" "You can only take out of a system the same amount of energy as you put back in, with no pollution or waste". He also admitted that "There has never been, nor is there now, a sustainable business or a sustainable fashion on this planet."

Another important point is the awareness of the consumers or communities in general. If you knew purchasing certain products and services helped save the planet, would you pay more for them? According to a recent report from Nielsen ${ }^{16}$ most of the world's consumers would. Over 30,000 consumers in 60 countries were polled in 2015 about their purchasing behavior with 66 per cent of them prepared to pay more for sustainable brands-an $11 \%$ increase from the previous year. In 2014, a global average of 55\% of respondents in Nielsen's corporate social responsibility survey said they were willing to pay extra when companies are committed to positive social and environmental impact. These results are very encouraging but it is too early to be optimistic.

\section{Conclusion}

There are clear evidences that the sustainable fashion is moving to become the mainstream in the fashion industry. Various research and studies ${ }^{17-24}$ are confirming or supporting this trend. Regarding the sustainability, textiles and apparel manufacturing practices have a significant impact on both environmental and social welfare.
Hence, fashion companies and apparel manufacturers should adopt a consumer focus when rethinking their sustainable supply chain. However, it is still not enough for most fashion companies to produce fashion clothing in a sustainable production system and develop them by sustainable and recyclable materials. The use of natural and new biodegradable fibers should be promoted. On the other hand, possible limitation in farming land use in near future because of food shortage due to the increasing world population should be kept in mind. Fashion companies are encouraged to provide more detailed and transparent information about production of sustainable fashion, which is beneficial for the consumption of sustainable fashion, and also stimulating consumers' purchase decision. The availability of relevant information is an effective way to educate fashion consumers and improve their awareness towards sustainability. These efforts should not be limited with fashion companies, all suppliers on the textile and apparel supply chain and consumers together with the manufacturers and retailer need to participate and demonstrate their commitment.

\section{Acknowledgments}

I have received no support or contribution to acknowledge.

\section{Conflicts of interest}

I have no conflicts of interest to declare.

\section{References}

1. Marsh GP. Man and Nature: or, Physical Geography as Modified by Human Action. Cambridge: Belknap Press of Harvard University Press; 1864. p. 582.

2. National Research Council. Sustainability and the US EPA. The National Academies Press, Washington, USA; 2011.

3. Samuelson PA. Economic Theory and Mathematics--An Appraisal. The American Economic Review. 1952;42(2):56-66.

4. WCED. Our Common Future. World Commission on Environment and Development. Oxford University Press; 1987. p. 1-247.

5. Blackburn RS. Sustainable textiles: Life cycle and environmental impact. Cornwall; Woodhead Publishing; 2009. p. 416.

6. Green Peace. The Detox Campaign. 2011.

7. ZDHC Programme. Durable Water and Soil Repellent Chemistry in the Textile Industry-A Research Report. P05 Water Repellency Project. 2012. p. 1-52

8. EHSC. Royal Society of Chemistry: Legal and Ethical Responsibilities for Environmental Protection. Environment, Health and Safety Committee. London, UK; 2002. p. 1-6.

9. Choudhury AKR. Green Chemistry and Textile Industry. J Textile Engineering \& Fashion Technology. 2017;2(3):1-12.

10. Clark JH. Green Separation Processes. In: Afonso CAM, Crespo JG, editors. Weinheim: Wiley-VCH Verlag, 2005. p. 383.

11. Poliakoff M, Licence P. Sustainable technology: Green Chemistry. Nature. 2007;450(7171):810-812.

12. Kawamura Y. Fashion-ology: An Introduction to Fashion Studies. Berg, Oxford, USA; 2005. p. 120.

13. Aakko M, Koskennurmi-Sivonen R. Designing Sustainable Fashion: Possibilities and Challenges. Research $J$ Textile \& Apparel. $2013 ; 17(1): 13-22$. 
14. Papanek V. Design for the Real World: Human Ecology and Social Change. 2nd ed. J Design History. 1984;6(4):307-310.

15. Chouinard Y. Sustainable Fashion: Why Now? A conversation about issues, practices, and possibilities. In: J Hethorn, C Ulasewicz, editors. Fairchild, New York, USA; 2008. p. 488.

16. Nielsen's 2015. Global Corporate Sustainability Report. 2016.

17. Niinimäki K, Hassi L. Emerging design strategies in sustainable production and consumption of textiles and clothing, $J$ Cleaner Production. 2011;19:1876-1883.

18. Shen B, Zheng JH, Chow PS, et al. Perception of fashion sustainability in online community. J Textile Institute. 2014;105(9):971-979.

19. Cervellon M, Wernerfelt A. Knowledge sharing among green fashion communities online: Lessons for the sustainable supply chain. J Fashion Marketing \& Management. 2012;16(2):176-192.

20. Laitala K, Boks C, Klepp IG. Making Clothing Last: A Design Approach for Reducing the Environmental Impacts. International J Design. 2015;9(2):93-107.
21. Elisa d'Avolio, Bandinelli R, Rinaldi R. Improving new product development in the fashion industry through product lifecycle management: a descriptive analysis. International J of Fashion Design, Technology \& Education. 2015;8(2):108-121.

22. Lee N, Choi YJ, Youn C, et al. Does Green Fashion Retailing Make Consumers More Eco-friendly? The Influence of Green Fashion Products and Campaigns on Green Consciousness and Behavior. Clothing \& Textiles Research J. 2012;30(1):67-82.

23. Curwen LG, Park J, Sarkar AK. Challenges and Solutions of Sustainable Apparel Product Development: A Case Study of Eileen Fisher. Clothing \& Textiles Research J. 2012;31(1):32-47.

24. Kumar V, Agrawal TK, Wang L, et al. Contribution of traceability towards attaining sustainability in the textile sector. Textiles \& Clothing Sustainability. 2017;3(5). 